\title{
STUDI KOMPARATIF PEMIKIRAN ISMAIL RAJI AL-FARUQI DAN SYED MUHAMMAD NAQUIB AL-ATTAS
}

\author{
IRMA SURYANI SIREGAR \\ Sekolah Tinggi Agama Islam Barumun Raya \\ Jln. Ki Hajar Dewantara, No. 66 Kab. Padanglawas Kode Pos 22763 \\ e-mail: irmasuryanisiregar2@gmail.com \\ LINA MAYASARI SIREGAR \\ Sekolah Tinggi Agama Islam Barumun Raya \\ Jln. Ki Hajar Dewantara, No. 66 Kab. Padanglawas Kode Pos 22763 \\ e-mail: linamayasarisiregar21@gmail.com
}

\begin{abstract}
Abstrak: Menurut Echols dan Hasan Sadily, kata Islamisasi berasal dari bahasa Inggris islamization yang berarti pengislaman. Ketika mendengar istilah Islamisasi Ilmu pengetahuan, ada sebuah kesan bahwa ada sebagian ilmu yang tidak Islam sehingga perlu untuk diislamkan. Berbicara tentang islamisasi ilmu pengetahuan, biasanya rujukannya berpusat pada dua tokoh utama, yaitu Syed Muhammad Naquib Al-Attas dan Ismail Raji Al Faruqi. Antara al-Attas dengan al-Faruqi mempunyai kesamaan pandangan, seperti pada tataran epistemologi mereka sepakat bahwa ilmu tidak bebas nilai (value free) tetapi terikat (value bound) dengan nilai-nilai yang diyakini kebenarannya. Mereka juga sependapat bahwa ilmu mempunyai tujuan yang sama yang konsepsinya disandarkan pada prinsip metafisika, ontologi, epistemologi dan aksiologi dengan tauhid sebagai kuncinya. Walaupun cukup banyak persamaan yang terdapat di antara keduanya, dalam beberapa hal, secara prinsip, mereka berbeda. Untuk mensukseskan proyek Islamisasi, al-Attas lebih menekankan kepada subjek daripada ilmu, yaitu manusia, dengan melakukan pembersihan jiwa dan menghiasinya dengan sifat-sifat terpuji, sehingga dalam proses Islamisasi ilmu tersebut dengan sendirinya akan terjadi transformasi pribadi serta memiliki akal dan rohani yang telah menjadi Islam secara kaffah. Sedangkan al-Faruqi lebih menekankan pada objek Islamisasi yaitu disiplin ilmu itu sendiri.
\end{abstract}

Kata Kunci: Studi Komparatif, Pemikiran, Al-Faruqi, Al-Attas

\section{PENDAHULUAN}

1. Biografi Singkat Syed Muhammad Naquib Al-Attas dan Karyakaryanya

Prof. Dr. Syed Muhammad Naquib Al-Attas, lahir di Bogor, Jawa Barat pada tanggal 5 september 1931. ayahnya bernama Syed Ali bin Abdullah Al-Attas, sedang ibunya bernama Syarifah Raguan al-Idrus, keturunan kerabat raja-raja Sunda Sukapura, Jawa Barat. Ayahnya berasal dari Arab yang silsilahnya merupakan keturunan ulama dan ahli tasawwuf.

Riwayat hidup beliau dimulai sejak ia berusai 5 tahun. Ketika itu ia berada di kohor baru, tinggal bersama saudara ayahnya sampai perang dunia kedua meletus. Pada tahun 1936-1941 ia belajar di Ngee Neng English Premary School di Johor Baru. Pada masa jajahan Jepang, Al-Attas kembali ke tempat kelahirannya di Indonesia, di sana beliau belajar tentang ilmu-ilmu keislaman di 
pesantren Urwatul-Wutsqo Sukabumi selama empat tahun, kemudian kembali lagi ke Johor dan hidup bersama salah satu familinya yang menjabat di kementrian Johor. Kemudian masuk sekolah militer dan menjadi anggota kemiliteran. Kepandaian dan kecemerlangan beliau dalam kemeliteran telah menjadikan beliau orang yang terpercaya di kalangan petinggi militer hingga beliau diberikan peluang untuk meneruskan studi kemiliterannya di salah satu sekolah militer yang terkemuka. Namun hidup beliau di dunia kemiliteran tidak bertahan, hanya sampai tingkat letnan dan beliau keluar.

Setelah keluar dari kemiliteran, beliau meneruskan studinya di Universitas Malaya pada tahun 19571959, lalu melanjutkan ke Mc Gill University Kanada, dimana beliau mendapatkan gelar MA (Master or Art). Kemudian Al-Attas mendapatkan sponsor untuk melanjutkan kuliahnya lagi ke program pasca sarjana di University of London pada tahun 1963-1964, disana ia meraih gelar Ph.D dengan predikat cumlaude tahun 1965.

Dilihat dari sekian almamater yang beliau tempuh, seharusnya beliau mempunyai corak pemikiran yang kebarat-baratan, karena dua almamater terakhirnya yang ada di Barat telah memberikan sumbangan yang besar padanya dalam bidang keilmuan, yang sekiranya bisa menarik empatinya hingga corak kebaratan bisa dengan gampang melekat pada beliau. Namun tidak, ternyata corak pemikiran beliau sangat berpolakan keislaman yang kental, dan beliau betul-betul mempunyai komitmen keilmuan yang tinggi, bahkan kalau kita amati secara global, Al-Attas mempunyai pandangan yang negatif terhadap Barat, sehingga munculnya konsep ta'dib dan ide Islamisasi pendidikan. Pemikiran beliau tersebut merupakan implementasi dari kekecewaan beliau pada wajah Pendidikan Islam yang sudah banyak dipolakan dengan corak barat (Abudin Nata, 2005: 141).

Maka di sini jelas bahwa pemikiran Al-Attas lebih didominasi oleh pemikiran-pemikiran keislaman yang hal itu merupakan perwujudan dari dokrtindoktrin keislaman yang beliau dapatkan baik itu di pesantern, sekolah maupun di rumahnya yang kental dengan suasana keislaman.

Al-Attas telah menulis 26 buku dan artikel-artikel, baik dalam bahasa Inggris maupun Melayu dan banyak yang telah diterjemahkan ke dalam bahasa lain, seperti bahasa Arab, Persia, Turki, Urdu, Malayalam, Indonesia, Prancis, Jerman, Rusia, Bosnia, Jepang, India, Korea, dan Albania. Di antara karyakaryanya tersebut adalah:

1. Islam and Secularism, ABIM, Kuala Lumpur, 1978. diterjemahkan ke dalam bahasa Melayu, India, Persia, Urdu, Indonesia, Turki, Arab, dan Rusia.

2. Islam and the Philoshophy of Science, ISTAC, Kuala Lumpur, 1989. diterjemahkan ke dalam bahasa Indonesia, Bosnia, Persia, dan Turki.

3. Islam: Paham Agama dan Asas Akhlak, ABIM, Kuala, Lumpur, 1977. versi bahasa Melayu

4. Risalah untuk Kaum Muslimin, monograf yang belum diterbitkan, 286 h., ditulis antara Februari-Maret 1973. (buku ini kemudian diterbtkan di Kuala Lumpur oleh ISTAC pada 2001penerj.)

5. The Mysticism of Hamzah Fanshûrî, University of Malaya Press, Kuala Lumpur, 1969

6. "Islamic Culture in Malaysia", Malaysian Society of Orientalist, Kuala Lumpur, 1966

7. "Rampaian Sajak", Bahasa, Persatuan Bahasa Melayu Universiti Malaya no. 9, Kuala Lumpur, 1968.

8. "Indonesia: 4 (a) History: The Islamic Period", Encyclopedia of Islam, edisi baru, E.J. Brill, Leiden, 1971. 
9. "A General Theory of The Islamization of the Malay Archipelago", Profiles of Malay Culture, Historiographi, Religion, and Politics, editor Sartono Kartodirdjo, Menteri Pendidikan dan Kebudayaan, Jakarta, 1976

\section{Biografi Singkat Ismail Raji Al Faruqi dan Karya-karyanya}

Ismail Raji Al Faruqi dilahirkan di daerah Jaffa, Palestina, pada 1 Januari 1921, sebelum wilayah ini diduduki Israel (Azyumardi Azra, 1996: 49). Saat itu Palestina masih begitu harmonis dalam pelukan kekuasaan Arab. Al Faruqi melalui pendidikan dasarnya di College des Freres, Lebanon sejak 1926 hingga 1936. Pendidikan tinggi ia tempuh di The American University, di Beirut. Gelar sarjana muda pun ia gapai pada 1941. Lulus sarjana, ia kembali ke tanah kelahirannya menjadi pegawai di pemerintahan Palestina, di bawah mandat Inggris selama empat tahun, sebelum akhirnya diangkat menjadi gubernur Galilea yang terakhir. Namun pada 1947 provinsi yang dipimpinnya jatuh ke tangan Israel, hingga ia pun hijrah ke Amerika Serikat.

Di negeri Paman Sam itu garis hidupnya berubah. Dia dengan tekun menggeluti dunia akademis. Di negeri ini pula, gelar masternya di bidang filsafat ia raih dari Universitas Indiana, AS, pada 1949, dan gelar master keduanya dari Universitas Harvard, dengan judul tesis On Justifying The God: Metaphysic and Epistemology of Value (Tentang Pembenaran Kebaikan: Metafisika dan Epistemologi Ilmu). Namun apa yang dicapai ini tidak memuaskannya, sehingga ia kemudian mendalami ilmuilmu keislaman di universitas al Azhar Cairo (Azyumardi Azra, 1996: 49). Sementara gelar doktornya diraih dari Universitas Indiana.

Tak hanya itu, Al Faruqi juga memperdalam ilmu agama di Universitas Al Azhar, Kairo, Mesir selama empat tahun. Usai studi Islam di Kairo, Al Faruqi mulai berkiprah di dunia kampus dengan mengajar di Universitas McGill, Montreal, Kanada pada 1959 selama dua tahun. Pada tahun 1962 Al Faruqi pindah ke Karachi, Pakistan, karena terlibat kegiatan Central Institute for Islamic Research.

Setahun kemudian, pada 1963, Al Faruqi kembali ke AS dan memberikan kuliah di Fakultas Agama Universitas Chicago, dan selanjutnya pindah ke program pengkajian Islam di Universitas Syracuse, New York. Pada tahun 1968, ia pindah ke Universitas Temple, Philadelphia, sebagai guru besar dan mendirikan Pusat Pengkajian Islam di institusi tersebut.

Selain itu, ia juga menjadi guru besar tamu di berbagai negara, seperti di Universitas Mindanao City, Filipina, dan di Universitas Qom, Iran. Ia pula perancang utama kurikulum The American Islamic College Chicago. Al Faruqi mengabdikan ilmunya di kampus hingga akhir hayatnya, pada 27 Mei 1986, di Philadelphia.

Tetapi sangat disayangkan aktifitas Al-Faruqi dan kepiawaiannya harus berakhir dengan peristiwa yang sangat tragis, ia meningggal dunia pada 27 Mei 1986 bertepatan dengan 17 Ramadhan $1406 \mathrm{H}$ bersama istrinya Lamiya Al-Faruqi dalam peristiwa pembunuhan secara brutal oleh orang yang tak dikenal, di rumah mereka Wyncote, Philadelphia. Menjelang sahur, tiga orang tak dikenal menyelinap masuk ke rumahnya dan dengan kejam keluarga ini dibunuh dan tewas seketika. AlFaruqi ditikam lebih dari 13 kali, dua di antaranya mengenai jantungnya yang membuatnya wafat seketika. Demikian juga dengan istrinya ditusuk sebanyak delapan tusukan. Dua di antaranya mengenai dadanya. Sedangkan putrinya Ammar yang memergoki pembunuhan tersebut berhasil diselamatkan dengan 200 luka jahitan di sekujur tubuhnya. 
Misteri pembunuhan itu berkaitan erat dengan kecamannya terhadap zionisme Israel serta dukungannya kepada rakyat Palestina yang merupakan tanah airnya.

Ismail Raji Al-Faruqi adalah sosok ideal, bibit unggul, pemikir dan ulama ternama dalam dunia pendidikan dan dakwah Islam. Yang dengan gigih memperjuangkan Islam dan negaranya Palestina. Dari karir yang ia lalui terlihat jelas kiprahnya sebagai seorang yang dapat dimasukkan dalam barisan nasionalis yang agamis. Dikatakan "nasionalis", karena tercermin pada penolakannya terhadap zionis Israel yang ingin menguasai negaranya Palestina, meskipun berujung pada kematian. Dan dikatakan "agamis", karena terlihat pada aktivitasnya yang dengan gencar mengusung gagasan islamisasi ilmu pengetahuan melalui lembaga kajian yang didirikannya. Al-Faruqi secara luas dikenal sebagai ahli ilmu agama Islam dan ilmu perbandingan agama. Ia juga dikenal sebagai penganjur Pan-Islamisme.

Al-faruqi mewariskan tidak kurang dari 100 artikel dan 25 judul buku, yang mencakup berbagai persoalan; etika, seni, sosiologi, kebudayaan, metafisika, dan politik. Di antara karyanya yang terpenting adalah: Islamization of Knowledge: General Principles and Workplan (1982) (diterjemahkan kedalam bahasa indonesia dengan judul Islamisasi Pengetahuan), A Historical Atlas of the Religion of The World (Atlas Historis Agama Dunia), Trialogue of Abrahamic Faiths (Trilogi Agama-agama Abrahamis), The Cultural Atlas of Islam (1986) (diterjemahkan dengan judul Atlas Budaya Islam; Menjelajah Khazanah Peradaban Gemilang ), Islam and Culture (1980) (Islam dan Kebudayaan), Al Tawhid; Its Implications for Thought and Life (1982), Islamic Thought and Culture, Essays in Islamic and Comparative Studies.

\section{SEJARAH IDE ISLAMISASI ILMU PENGETAHUAN}

Menurut Wan Mohd Nor Wan Daud, proses Islamisasi ilmu pengetahuan pada dasarnya telah berlangsung sejak permulaan Islam hingga zaman kita sekarang ini. Ayat-ayat terawal yang diwahyukan kepada nabi secara jelas menegaskan semangat Islamisasi ilmu pengetahuan kontemporer, yaitu ketika Allah menekankan bahwa Dia adalah sumber dan asal ilmu manusia (Wan Mohd Nor Wan Daud, 1998: 341). Ide yang disampaikan al-Qur'an tersebut membawa suatu perubahan radikal dari pemahaman umum bangsa Arab praIslam, yang menganggap suku dan tradisi kesukuan serta pengalaman empiris, sebagai sumber ilmu pengetahuan dan kebijaksanaan.

Pada sekitar abad ke-8 masehi, pada masa pemerintahan Daulah Bani Abbasiyah, proses Islamisasi ilmu ini berlanjut secara besar-besaran, yaitu dengan dilakukannya penterjemahan terhadap karya-karya dari Persia dan Yunani yang kemudian diberikan pemaknaan ulang disesuaikan dengan konsep Agama Islam (Rosnani Hashim, 2005: 32). Peradaban Islam telah mencapai kemajuan ilmu dalam banyak bidang pada masa itu. Sarjana Islam telah berhasil menerjemah, menyaring, menyerap dan memadukan ilmu asing ke dalam pandangan mereka berdasarkan alQur'an. Ilmu Pengetahuan yang merupakan jantung peradaban dan kebudayaan Islam telah membimbing umat Islam ke arah puncak kegemilangannya.

Akan tetapi pada beberapa kurun berikutnya, daya keilmuan dan kekuatan umat Islam mulai pudar karena beberapa faktor. Malapetaka yang paling besar yaitu penyerangan Mongol yang dipimpin oleh Hulagu Khan ke Baghdad yang memusnahkan perpustakaan dan pembakaran buku-buku karya asli sarjana Islam. Selain itu terjadinya perang salib 
yang berkepanjangan menjadi penyebab kemunduran umat Islam.

Pengaruh pemindahan ilmu dari Andalusia ke Eropa, merangsang warga Eropa bangkit dan memelopori berbagai bidang ilmu pada era Renaisans. Mereka mengambil alih tongkat kepemimpinan intelektual dan fisikal dari umat Islam, khususnya setelah Revolusi Industri. Pada abad pertengahan (medieval times) banyak berkembang faham Barat yang mencoba memisahkan ilmu pengetahuan dengan agama. Sebut saja Nietzsche, dia berargumen bahwa agama tidak bisa disesuaikan dengan ilmu pengetahuan. Ia menambahkan, "seseorang tidak dapat mempercayai dogma-dogma agama dan metafisika jika seseorang memiliki metode-metode yang ketat untuk meraih kebenaran di dalam hati. Antara ilmu pengetahuan dan agama masing-masing menempati bidang yang berbeda". Dari ungkapan tersebut nampaknya ada indikasi bahwa ia tidak menginginkan nilai-nilai Islam masuk ke dalam pembahasan ilmu pengetahuan modern. Sekularisasi ilmu pengetahuan menjadi fondasi utama dalam sepanjang sejarah peradaban Barat modern. Dengan adanya sekularisasi ilmu pengetahuan, sedikit demi sedikit akan memisahkan jarak antara ilmu dengan agama, melenyapkan wahyu (Al-Quran) sebagai sumber ilmu, dan juga memisahkan wujud dari yang sakral. Selain itu sekularisasi ilmu juga telah menjadikan rasio sebagai basis keilmuan secara mutlak, dan mengaburkan maksud serta tujuan ilmu yang sebenarnya menjadi keraguan dan dugaan sebagai metodologi ilmiah.

Sebagai solusi untuk menghadapi krisis epistemologi yang sedang melanda segala bentuk pemikiran dan juga sebagai jawaban dari berbagai tantangan yang muncul dari hegemoni westernisasi ilmu, maka perlu kiranya menghadirkan suatu gagasan islamisasi ilmu pengetahuan, yang mana dalam bahasa Arab istilah islamisasi ilmu disebut juga dengan "islamiyyat al-ma'rifat, atau bahasa Inggris disebut sebagai "islamization of knowledge".

Usaha islamisasi ilmu pada dasarnya telah terjadi sejak masa Rasulullah SAW dan para sahabatnya, yang waktu itu diturunkan Al-Quran dengan bahasa Arab, sehingga dengannya mampu mengubah watak serta pandangan hidup (worldview) dan tingkah laku bangsa Arab. Oleh karena itu, wacana islamisasi ilmu bukanlah suatu yang baru, hanya saja dalam konteks operasionalnya pengislaman ilmu-ilmu masa kini dicetuskan oleh tokoh-tokoh ilmuwan islam (Wan Mohd Nor Wan Daud, 1998: 390).

Contohnya saja pada tahun 30 -an, Muhammad Iqbal menegaskan akan perlunya melakukan proses Islamisasi terhadap ilmu pengetahuan. Beliau menyadari bahwa ilmu yang dikembangkankan oleh Barat telah bersifat ateistik, sehingga bisa menggoyahkan aqidah umat, sehingga beliau menyarankan umat Islam agar "mengonversikan ilmu pengetahuan modern". Akan tetapi, Iqbal tidak melakukan tindak lanjut atas ide yang dilontarkannya tersebut. Tidak ada identifikasi secara jelas problem epistimologis mendasar dari ilmu pengetahuan modern Barat yang sekuler itu, dan juga tidak mengemukakan saransaran atau program konseptual atau metodologis untuk megonversikan ilmu pengetahuan tersebut menjadi ilmu pengetahuan yang sejalan dengan Islam (Wan Mohd Nor Wan Daud, 1998: 390). Sehingga sampai saat itu, belum ada penjelasan yang sistematik secara konseptual mengenai Islamisasi ilmu pengetahuan.

Ide Islamisasi ilmu pengetahuan ini dimunculkan kembali oleh syed Hossein Nasr, pemikir muslim Amerika kelahiran Iran, tahun 60-an. Beliau menyadari akan adanya bahaya sekularisme dan modernisme yang 
mengancam dunia Islam, karena itulah beliau meletakkan asas untuk konsep sains Islam dalam aspek teori dan praktikal melalui karyanya Science and Civilization in Islam (1968) dan Islamic Science (1976). (Rosnani Hashim, 2005: 32). Nasr bahkan mengklaim bahwa ideide Islamisasi yang muncul kemudian merupakan kelanjutan dari ide yang pernah dilontarkannya (Wan Mohd Nor Wan Daud, 1998: 402).

Selanjutnya gagasan islamisasi ilmu pengetahuan tersebut dilanjutkan pada saat diselenggarakan sebuah Konferensi Dunia yang pertama tentang Pendidikan Muslim di Mekkah pada tahun 1977. Konperensi yang diprakarsai dan dilaksanakan oleh King Abdul Aziz University ini berhasil membahas 150 makalah yang ditulis oleh sarjana-sarjana dari 40 negara, dan merumuskan rekomendasi untuk pembenahan dan penyempurnaan sistem pendidikan Islam yang diselenggarakan oleh umat Islam di seluruh dunia. Salah satu gagasan yang direkomendasikan adalah menyangkut islamisasi pengetahuan. Gagasan ini antara lain dilontarkan oleh Syed Muhammad Naquib Al-Attas dalam makalahnya yang berjudul Preliminary Thoughts on the Nature of Knowledge and the Definition and the Aims of Education, yang kemudian dijadikan sebagai salah satu bab dari bukunya yang berjudul Islam dan Sekularisme (Terj. 1981), dan Ismail Raji Al-Faruqi dalam makalahnya islamicizing Social Science, menunjukkan kelemahan-kelemahan dari metodologi Barat dan memberikan konsep ilmu-ilmu yang islami (Muhaimin, 2006: 37-38).

Persidangan inilah yang kemudian dianggap sebagai pembangkit proses Islamisasi selanjutnya. Jadi Islamisasi ilmu menjadi kekuatan baru dalam khazanah dunia Islam sebagai respon terhadap perkembangan ilmu pengetahuan masa kini. Hal ini sejaln dengan yang disebut Sholeh (2017: 2010) bahwa Islamisasi inilah yang diasumsikan sebagai perebut tonggak kejayaan yang pernah diraih oleh umat Islam ketika di Spanyol.

\section{ISLAMISASI ILMU PENGETAHUAN SYAID NAQUIB AL-ATTAS}

Pemikiran al-Attas berawal dari keprihatinannya terhadap penyempitan makna terhadap istilah-istilah ilmiah Islam yang disebabkan oleh upaya westernisasi, mitologisasi, pemasukan hal-hal yang magis (gaib) dan sekularisasi. Sebagai jawaban untuk menanggulangi distorsi atau bahkan mengembalikannya pada proporsi yang sebenarnya, maka al-Attas memperkenalkan konsep islamisasi ilmu pengetahuan sebagai langkah awal membangun paradigma pemikiran Islam kontemporer.

Islamisasi ilmu pengetahuan menurut Al-Attas adalah "Pembebasan manusia dari tradisi magis, mitologis, animistis, kultur-nasional (yang bertentangan dengan Islam) dan dari belenggu paham sekuler terhadap pemikiran yang hakiki...Juga pembebasan dari kontrol dorongan fisiknya yang cenderung sekuler dan tidak adil terhadap hakikat diri atau jiwanya, sebab manusia dalam wujud fisiknya cenderung lupa terhadap hakikat dirinya yang sebenarnya, dan berbuat tidak adil terhadapnya. Islamisasi adalah suatu proses menuju bentuk asalnya yang tidak sekuat proses evolusi dan devolus" (Wan Mohd Nor Wan Daud, 1998: 336).

Ini bermakna bahwa umat Islam semestinya memiliki akal yang terbebas dari pengaruh magis, mitos, animisme, nasionalisme buta dan sekularisme. Islamisasi juga membebaskan manusia dari sikap tunduk kepada keperluan jasmaninya yang cenderung menzhalimi dirinya sendiri, karena sifat jasmani adalah cenderung lalai terhadap hakikat dan asal muasal manusia. Dengan demikian, islamisasi tidak lain adalah proses pengembalian kepada fitrah, 
sehingga dengan demikian umat Islam akan terbebaskan dari belenggu hal-hal yang bertentangan dengan Islam.

Menurut Al-Attas tantangan besar yang dihadapi umat pada saat ini adalah ilmu pengetahuan yang telah kehilangan tujuannya. Menurut al-Attas, ilmu pengetahuan yang ada saat ini adalah produk dari kebingungan skeptisme yang meletakkan keraguan dan spekulasi sederajat dengan metodologi ilmiah dan menjadikannya sebagai alat epistemologi yang valid dalam mencari kebenaran (Wan Mohd Nor Wan Daud, 1998: 330). Selain itu, ilmu pengetahuan masa kini dan modern, secara keseluruhan dibangun, ditafsirkan, dan diproyeksikan melalui pandangan dunia, visi intelektual, dan persepsi psikologis dari kebudayaan dan peradaban Barat. Jika pemahaman ini merasuk ke dalam pikiran elite terdidik umat Islam, maka akan sangat berperan timbulnya sebuah fenomena berbahaya yang diidentifikasikan oleh al-Attas sebagai "deislamisasi pikiran- pikiran umat Islam". Oleh karena itulah, sebagai bentuk keprihatinannya terhadap perkembangan ilmu pengetahuan ia mengajukan gagasan tentang "Islamisasi Ilmu Pengetahuan Masa Kini" (Wan Mohd Nor Wan Daud, 1998: 333-335) serta memberikan formulasi awal yang sistematis yang merupakan prestasi inovatif dalam pemikiran Islam modern.

Al-Attas menolak pandangan bahwa Islamisasi ilmu bisa tercapai dengan melabelisasi ilmu sekuler dengan Islam. Usaha yang demikian hanya akan memperburuk keadaan dan tidak ada manfaatnya selama "virus"nya masih berada dalam tubuh ilmu itu sendiri sehingga ilmu yang dihasilkan pun jadi mengambang, Islam bukan dan sekulerpun juga bukan. Padahal tujuan dari Islamisasi itu sendiri adalah untuk melindungi umat Islam dari ilmu yang sudah tercemar yang menyesatkan dan menimbulkan kekeliruan. Islamisasi, kata Al-Attas, adalah sebuah "revolusi epistemologi" dan harapan untuk merealisasikan kebangkitan Islam. Konsep Islamisasi menjadi tumpuan minda dan jiwa beliau semenjak sekian lama sebelum tertuang menjadi gagasan besar. Islamisasi yang dimaksudkan alAttas bukan sekedar merubah disiplin ilmu tapi Islamisasi pikiran, jiwa dan raga serta kesan-kesannya terhadap kehidupan manusia. Islamisasi ilmu dimaksudkan untuk mengembangkan kepribadian muslim yang sebenarnya sehingga menambah keimanannya kepada Allah, dan dengan Islamisasi tersebut akan terlahirlah keamanan, kebaikan, keadilan dan kekuatan iman (Rosnani Hashim, 2005: 32). Sehingga dengan ilmu seorang muslim diharapkan akan semakin bertambah keimanannya.

Menurut al-Attas, untuk melakukan Islamisasi ilmu pengetahuan tersebut ada beberapa hal yang harus dilakukan, yaitu: Pertama, Seseorang yang mengislamkan ilmu perlu memenuhi pra-syarat, yaitu ia harus mampu mengidentifikasi pandangan-hidup Islam sekaligus mampu memahami budaya dan peradaban Barat. Kedua, Islamisasi ilmu pengetahuan kontemporer melibatkan dua proses: a) Mengisoliir unsur-unsur dan konsep-konsep kunci yang membentuk budaya dan peradaban Barat dari setiap bidang ilmu pengetahuan modern saat ini, khususnya dalam ilmu pengetahuan humaniora. Bagaimanapun, ilmu alam, fisika dan aplikasi harus diislamkan juga khususnya dalam penafsiran akan fakta-fakta dan dalam formulasi teori-teori. b) Memasukkan unsur-unsur Islam beserta konsepkonsep kunci dalam setiap bidang dari ilmu pengetahuan saat ini yang relevant.

1. Membebaskan manusia dari magik, mitologi, animisme, tradisi budaya nasional yang bertentangan dengan Islam, dan kemudian dari kontrol sekular kepada akal dan bahasanya.

2. Membebaskan akal manusia dari keraguan (shakk), dugaan (Đzann) dan 
argumentasi kosong (mira') menuju keyakinan akan kebenaran mengenai realitas spiritual, intelligible dan materi

3. Mengeluarkan penafsiran-penafsiran ilmu pengetahuan kontemporer dari ideologi, makna dan ungkapan sekular.

Untuk melancarkan pemikirannya tersebut, pada tahun 1987, Al-Attas mendirikan institusi pendidikan tinggi bernama International Institute of Islamic Thought and Civilization (Istac) di Kuala Lumpur. Pendirian lembaga ini juga ada campur tangan tokoh politik Malaysia Anwar Ibrahim.

Lembaga ini juga menjadi lembaga pemikiran di Malaysia saat Mahathir Mohammad dan Anwar Ibrahim ingin mendirikan "Islam Peradaban". Yakni suatu megaprojek untuk mengembalikan kejayaan Islam. Melalui institusi ini AlAttas bersama sejumlah kolega dan mahasiswanya melakukan kajian dan penelitian mengenai Pemikiran dan Peradaban Islam, serta memberikan respons yang kritis terhadap Peradaban Barat.

Gagasan dan saran-saran konkrit yang diajukan al-Attas ini, tak pelak lagi, mengundang pelbagai reaksi dan salah satunya adalah Ismail Raji al-Faruqi dengan agenda Islamisasi Ilmu Pengetahuannya. Dan hingga saat ini gagasan Islamisasi ilmu menjadi misi dan tujuan terpenting (raison d'etre) bagi beberapa institusi Islam seperti International Institute of Islamic Thought (IIIT), Washington DC., International Islamic University Malaysia (IIUM), Kuala Lumpur, Akademi Islam di Cambridge dan International Institute of Islamic Thought and Civilization (ISTAC) di Kuala Lumpur (Rosnani Hashim, 2005: 32-33).

\section{ISLAMISASI ILMU PENGETAHUAN ISMAIL RAJI AL-FARUQI}

Pengertian islamisasi ilmu menurut Al-Faruqi adalah usaha untuk menyusun dan membangun kembali ilmu yaitu mendefinisikan kembali, menyusun ulang data, memikirkan kembali argumen dan rasionalisasi terkait dengan data itu, menilai kembali kesimpulan dan tafsiran, membentuk kembali tujuan dan melakukannya dalam kerangka visi dan perjuangan Islam. Seperti juga Al-Attas, Al-Faruqi menekankan pentingnya menyusun dan membangun kembali disiplin sains sosial, sains kemanusiaan dan sains alam dalam kerangka Islam dengan memadukan prinsip-prinsip Islam ke dalam tubuh ilmu tersebut.

Menurut Al-Faruqi, islamisasi ilmu dapat dicapai melalui pemaduan ilmuilmu baru kedalam khazanah warisan Islam dengan membuang, menata, menganalisa, menafsir ulang dan menyesuaikannya menurut nilai dan pandangan Islam. Dari sudut metodologi, Al-Faruqi mengemukakan ide islamisasi ilmunya dengan bersandar pada tauhid. Menurut pandangan beliau, metodologi tradisional tidak mampu memikul tugas ini karena beberapa kelemahan. Pertama, metodologi tradisional telah menyempitkan konsep utama seperti fiqh, faqih, ijtihad dan mujtahid. Kedua, kaidah tradisional telah memisahkan antara wahyu dan akal, dan selanjutnya memisahkan antara pemikiran dan tindakan. Ketiga, kaidah tradisional membuka ruang bagi dualisme sekular dan agama.

Sebaliknya, Al-Faruqi menggariskan beberapa prinsip dasar dalam pandangan Islam sebagai kerangka pemikiran, metodologi dan cara hidup Islam. Prinsip-prinsip tersebut ialah (1) keesaan allah, (2) kesatuan penciptaan, (3) kesatuan kebenaran, (4) kesatuan ilmu, (5) kesatuan kehidupan; dan (6) kesatuan kemanusiaan.

Secara umum, Islamisasi ilmu tersebut dimaksudkan untuk memberikan respon positif terhadap realitas ilmu pengetahuan modern yang sekularistik dan Islam yang "terlalu" religius, dalam model pengetahuan baru yang utuh dan integral tanpa pemisahan 
di antaranya. Sebagai panduan untuk usaha tersebut, al-Faruqi menggariskan satu kerangka kerja dengan lima tujuan dalam rangka Islamisasi ilmu, tujuan yang dimaksud adalah:

1. Penguasaan disiplin ilmu modern.

2. Penguasaan khazanah warisan Islam

3. Membangun relevansi Islam dengan masing-masing disiplin ilmu modern

4. Memadukan nilai-nilai dan khazanah warisan Islam secara kreatif dengan ilmu-ilmu modern

5. Pengarahan aliran pemikiran Islam ke jalan-jalan yang mencapai pemenuhan pola rencana Allah (Rosnani Hashim, 2005: 98).

Untuk merealisasikan tujuantujuan tersebut, al-Faruqi menyusun 12 langkah yang harus ditempuh terlebih dahulu. Langkah-langkah tersebut adalah:

1. Penguasaan disiplin ilmu modern: prinsip, metodologi, masalah, tema dan perkembangannya

2. Survei disiplin ilmu

3. Penguasaan khazanah Islam: ontologi

4. Penguasaan khazanah ilmiah Islam: analisis

5. Penentuan relevansi Islam yang khas terhadap disiplin-disiplin ilmu.

6. Penilaian secara kritis terhadap disiplin keilmuan modern dan tingkat perkembangannya di masa kini

7. Penilaian secara kritis terhadap khazanah Islam dan tingkat perkembangannya dewasa ini

8. Survei permasalahan yang dihadapi umat Islam

9. Survei permasalahan yang dihadapi manusia

10. Analisis dan sintesis kreatif

11. Penuangan kembali disiplin ilmu modern ke dalam kerangka Islam

12. Penyebarluasan ilmu yang sudah diislamkan (Rosnani Hashim, 2005: 99-118).

Dua langkah pertama untuk memastikan pemahaman dan penguasaan umat Islam terhadap disiplin ilmu tersebut sebagaimana yang berkembang di Barat. Dua langkah seterusnya adalah untuk memastikan sarjana muslim yang tidak mengenali warisan ilmu Islam karena masalah akses kepada ilmu tersebut mungkin disebabkan masalah bahasa akan berpeluang untuk mengenalinya dan antologi yang disediakan oleh sarjana Islam tradisional. Analisis warisan ilmu Islam adalah untuk memahami wawasan Islam dengan lebih baik dari sudut latar belakang sejarah, masalah dan isu yang terlibat.

Empat langkah pertama itu seharusnya dapat menjelaskan kepada cendekiawan tersebut tentang sumbangan warisan ilmu islam dan relevansinya kepada bidang yang dikaji oleh disiplin ilmu itu dan tujuan kasarnya. Langkah keenam adalah langkah paling utama dalam proses islamisasi ini dimana kepatuhan kepada prinsip pertama dan lima kesatuan akan diperiksa sebelum sintesis kreatif dicapai dalam langkah ke10.

Islamisasi ilmu pengetahuan, menurut Faruqi menghendaki adanya hubungan timbal balik antara realitas dan aspek kewahyuan, umat Islam harus memanfaatkan ilmu pengetahuan. Tanpa memanfaatkan ilmu pengetahuan dalam upaya memahami wahyu, umat Islam akan terus tertinggal oleh umat lainnya. Karena realitasnya, saat ini ilmu pengetahuanlah yang amat berperan dalam menentukan tingkat kemajuan umat manusia.

Secara sederhana Al Faruqi berpendapat bahwa ilmu pengetahuan yang saat ini tengah berkembang tidak semuanya bertentangan dengan nilai-nilai Islam. Dengan demikian, Faruqi menyarankan proses Islamisasi adalah melakukan penyaringan dari ilmu pengetahuan yang telah ada. Jika semua aspek ilmu tersebut tidak bertentangan dengan nilai-nilai Islam maka otomatis ilmu tersebut dapat dipakai dan dikembangkan lebih lanjut. Namun jika ada beberapa unsur dalam suatu ilmu 
tertentu yang bertentangan dengan nilainilai Islam, sebaiknya dilakukan proses penyesuaian dengan nilai-nilai Islam. Metode ini oleh Louay Safi dianggap sebagai metode integrasi antara teori dan tradisi keilmuan Islam dan keilmuan Barat yang sekuler (yang saat ini tengah eksis.

Karya Faruqi tentang Islamisasi ilmu pengetahuan yang banyak menjadi referensi para pemikir adalah Islamization of Knowledge: General Principles and Work Plan, yang diterbitkan oleh The International Institute of Islamic Thought (1989). Karya Faruqi ini banyak menjadi rujukan pakar lain dalam memahami dan mengembangkan Islamisasi ilmu pengetahuan.

Gagasan 'Islamisasi ilmu
pengetahuan tak hanya ia perjuangkan dalam bentuk buku, namun juga dalam institusi pengkajian Islam dengan mendirikan IIIT pada 1980, di Amerika Serikat. Kini, lembaga bergengsi dan berkualitas itu memiliki banyak cabang di berbagai negara, termasuk di Indonesia dan Malaysia. Namun pemikirannya juga menimbulkan pro-kontra di kalangan ilmuwan Muslim dan Barat.

Hal demikian tak membuatnya larut dalam kritikan. Suara-suara sumbang itu malah ia kelola sedemikian rupa sehingga berpotensi menjadi stimulasi pengembangan pemikirannya tersebut. Tak cukup dengan IIIT saja, ia dirikan pula The Association of Muslim Social Scientist pada 1972. Kedua lembaga internasional yang didirikannya itu menerbitkan jurnal Amerika tentang Ilmu-ilmu Sosial Islam.

Berbagai kegiatan ini ia lakukan semata didorong oleh pandangannya bahwa ilmu pengetahuan dewasa ini benar-benar telah sekuler dan karenanya jauh dari tauhid. Maka, dirintislah teori dan 'resep' pengobatan agar kemajuan dan pengetahuan tidak berjalan kebablasan di luar jalur etik, lewat konsep
Islamisasi ilmu dan paradigma tauhid dalam pendidikan dan pengetahuan.

\section{ANALISIS TERHADAP KONSEPSI ISLAMISASI ILMU AL-ATTAS DAN AL- FARUQI}

Analisis atas kerangka falsafah alAttas dan al-Faruqi menunjukkan bahwa mereka mempunyai asumsi yang sama tentang ilmu. Dari sudut epistemologi, mereka percaya bahwa ilmu tidak bebas nilai. Tujuan ilmu adalah satu dan sama. Mengenai konsepsi ilmu mereka bersandar kepada prinsip metafisik, ontologi, epistemologi dan aksiologi, dengan konsep tauhid sebagai kuncinya. Mereka juga yakin bahwa Tuhan adalah sumber asal segala ilmu dan ilmu adalah asas bagi kepercayaan dan amal salih. Bahkan, keduanya bersepakat bahwa akar masalah umat Islam terletak pada sistem pendidikan mereka, khususnya masalah dengan ilmu kontemporer, dimana penyelesaiannya terletak dalam islamisasi ilmu pengetahuan kini. Mereka sepakat dengan konsep Islamisasi ilmu kontemporer, yaitu satu pembedahan atas ilmu modern perlu dilakukan supaya unsur-unsur buruk dan tercemar dihapuskan, dianalisa, ditafsir ulang atau disesuaikan dengan pandangan dan nilai Islam.

Pada dasarnya semua pelopor ide Islamisasi ilmu, khususnya al-Attas, dan al-Faruqi, menyakini bahwa ilmu itu bukanlah neutral (Samsul Nizar, 204: 4649). atau bebas nilai. Tujuan usaha mereka adalah sama dan konsep Islamisasi ilmu yang mereka bawa adalah berpedoman kepada prinsip metafisik, ontologi, epistemologi dan aksiologi Islam yang berasaskan kepada konsep tauhid. Mereka sependapat bahwa ilmu Barat khususnya ilmu sains kemanusiaan, sains kemasyarakatan, dan sains alam modern bersandar pada falsafah dan pandangan yang sekuler di mana Allah yang Maha Esa telah dipinggirkan. Dalam kerangka ilmu ini, Allah tidak berperan. Mungkin 
mereka sependapat dengan Aristoteles tentang Tuhan dan penciptaan alam di mana alam ini laksana sebuah jam dan Tuhan umpama pencipta jam tersebut. Setelah jam itu dicipta, penciptanya tidak mempunyai peranan apa-apa lagi. Selain itu, golongan ini menganggap bahwa Tuhan tidak lagi mempunyai peran apaapa setelah Ia mencipta alam yang kini bergerak dengan sendiri melalui mekanisma cause dan effect. Pemikir ini juga sependapat bahwa metodologi ilmu modern ini banyak dipengaruhi oleh metodologi sains alamiah yang menekankan objektivitas tetapi telah melampaui batasan dengan wujudnya golongan berpaham positivistik yang menolak segala kenyataan atau hakikat yang tidak dapat dibuktikan secara empirikal.

Dan sudut epistemologi, falsafah yang didukung ini menentang ilmu yang bersumberkan wahyu maupun ilham dan cuma menerima akal dan pancaindera. Ilmu modern ini bukannya mengokohkan iman kepada Allah sebagaimana peranan ilmu yang hakiki dalam pandangan Islam, tetapi sebaliknya merusak dan menyesatkan aqidah umat Islam.

Walaupun cukup banyak persamaan yang terdapat di antara keduanya, dalam beberapa hal, secara prinsip, mereka berbeda. Untuk mensukseskan proyek Islamisasi, al-Attas lebih menekankan kepada subjek daripada ilmu, yaitu manusia, dengan melakukan pembersihan jiwa dan menghiasinya dengan sifat-sifat terpuji, sehingga dalam proses Islamisasi ilmu tersebut dengan sendirinya akan terjadi transformasi pribadi serta memiliki akal dan rohani yang telah menjadi Islam secara kaffah. Sedangkan al-Faruqi lebih menekankan pada objek Islamisasi yaitu disiplin ilmu itu sendiri. Hal ini mungkin saja menimbulkan masalah, khususnya ketika berusaha untuk merelevansikan Islam terhadap sains modern, karena bisa saja yang terjadi hanyalah proses labelisasi atau ayatisasi semata Begitu juga, langkah yang dianjurkan oleh alFaruqi mungkin menghadapi sedikit masalah khususnya ketika beliau merencanakan agar relevansi Islam terhadap sesuatu disiplin ilmu dikenal pasti dan dilakukan sintesis. Apabila ini dilakukan mungkin akan terjadi penempelan atau pemindahan saja, sebagaimana yang dikhawatirkan oleh al-Attas (Samsul Nizar, 2002: 124).

Bagi al-Attas islamisasi kepribadian seseorang individu itu mendahului Islamisasi ilmu. Dibanding dengan alFaruqi, al-Attas berhasil meyakinkan dengan jelas keperluan kepada Islamisasi ilmu pengetahuan sebagai respons terhadap sekularisasi. Sementara bagi alFaruqi faktor utama yang mendorong Islamisasi ilmu pengetahuan adalah kekalutan dan kemunduran ummah, sistem pendidikan dualistik dan kegagalan metodologi tradisional untuk berhadapan dengan realitas modern.

Satu lagi perbedaan yang kentara dalam pendekatan mereka melibatkan ruang lingkup ilmu pengetahuan yang ingin diislamisasikan. Al-Attas membatasi ilmu pengetahuan yang ingin diislamisasikan kepada ilmu pengetahuan kontemporer. Al-Faruqi yakin bahwa proses Islamisasi patut juga dilakukan terhadap ilmu turath islamiy seperti yang termaktub dalam kerangka kerjanya.

Selain itu, perbedaan yang sangat kentara di antara kedua pemikir ini adalah dalam metodologi proses Islamisasi ilmu itu. Bagi al-Attas, definisi Islamisasi ilmu pengetahuan itu sendiri memberi panduan kepada metode pelaksanaannya. Proses ini melibatkan dua langkah, yaitu, proses verifikasi atau saringan dan proses penyerapan. Beliau tidak menjelaskan prosedur-prosedur yang khusus. Mungkin beliau berkeyakinan bahwa apabila seorang individu itu memahami pandangan Islam, menafsirkannya dan menghayati nilainilai yang sesuai dengan pemahaman tersebut, maka islamisasi ilmu 
pengetahuan pun akan terlaksana. Seseorang akan mengetahui unsur-unsur dan konsep-konsep asing serta melakukan pembedahan yang diperlukan.

Sementara Al-Faruqi merumuskan satu kaidah untuk Islamisasi ilmu pengetahuan berdasarkan prinsip-prinsip pertamanya yang melibatkan 12 langkah. Kaedah al-Faruqi merangkum sintesis yang kreatif dan pemaduan konsep ilmu Barat dan Islam yang dirancang dapat menyerap ilmu Islam ke dalam ilmu modern dan sebaliknya ilmu modern ke dalam ilmu Islam. Tetapi menurut AlAttas ini mungkin terjadi hanya setelah menyaringkan unsur dan konsep Barat sekuler.

Perbedaan di antara konsepsi alFaruqi dan al-Attas juga amat jelas berkenaan dengan kepentingan tasawuf dalam merumuskan konsep-konsep dasar dalam semua cabang ilmu. Al-Faruqi mengecilkan peranan tasawuf dan berpendapat bahwa "kerohanian yang terpancar melalui tasawwuf hanya membawa kepada kelesuan dan karena itu ia beranggapan bahwa tasawuf itu sesuatu yang tidak perlu dan bahkan bisa merusak."

Semantara al-Attas menganggap tasawuf bukan saja penting tetapi perlu bagi perumusan teori ilmu dan pendidikan. Menurut beliau "perumusan falsafah pendidikan dan falsafah sains dalam acuan Islam tidak boleh dilakukan dengan mengabaikan sumbangan besar ulama-ulama sufi tentang hakikat realitas."

Di samping itu, ulama tradisional melihat tasawuf sebagai satu cara untuk memperoleh ilmu kerohanian, dan menganggap ilmu kerohanian sebagai cara utama bagi menyelamatkan manusia dari cengkaman empirisme, pragmatisme, materialisme dan rasionalisme sempit yang merupakan sumber utama sains modern. Justru itu ilmu kerohanian menjadi cara untuk mengatur pendidikan dan perspektif terpadu dan komprehensif.

Al-Faruqi memberi penekanan kepada transformasi sosial dibanding idealisme sufi yang memberi perhatian kepada perubahan individu. Dia mengutamakan masyarakat dan negara dibanding individu. Ini jelas sekali dan penekanan al-Faruqi kepada ummah. Bagaimanapun al-Attas menjelaskan memang benar ummah dan negara sangat penting dalam Islam, tetapi begitu juga dengan individu Muslim, sebab bagaimana ummah dan negara bisa dibangun jika individu Muslim tidak memahami tentang Islam dan pandangannya belum menjadi Muslim yang baik? Oleh karena itu, menurut al-attas strategi yang tepat sesuai dengan zaman dan keadaan kita, yang lebih penting adalah menekankan individu dalam mencari penyelesaian kepada masalah yang kita hadapi daripada menekankan masyarakat dan negara. Al-Attas mendukung intuisi sebagai sumber dan metode yang sah bagi metodologi saintifik.

Berbeda dengan pandangan alAttas, Al-Faruqi menentang keras metodologi tradisional khususnya yang dipengaruhi oleh tasawuf yang mendukung metodologi intuitif dan esoterik. Pada pandangannya metode ini menghasilkan pemisahan wahyu dan akal.

Perbedaan pandangan terhadap intuisi sebagai metode dan sumber ilmu mempunyai beberapa implikasi bagi konsep ilmu, pendidikan dan Islamisasi ilmu pengetahuan kontemporer dan islamisasi secara umum.

Seperti yang dijelaskan sebelum ini konsep Islamisasi al-Faruqi lebih menekankan masyarakat, ummah atau perubahan sosio-ekonomi dan politik. Malahan ia lebih gencar menyebarkan ide Islamisasi ilmu kepada massa melalui aktivitas tetap yang berbentuk seminar, persidangan dan membuka beberapa cabangnya di beberapa negara. Konsep islamisasi ilmu pengetahuan al-Attas juga 
memberi lebih perhatian kepada individu daripada masyarakat. Baginya perubahan individual akan diikuti oleh perubahan dalam masyarakat dan ummah.

\section{DAMPAK KONSEP ISLAMISASI ILMU PENGETAHUAN}

Ada beberapa dampak konsep islamisasi ilmu pengetahuan, yaitu:

1. Penolakan dan Penyaringan terhadap disiplin dan teori ilmu pengetahuan modern.

2. Pengkajian serius terhadap pemikiran para pemikir Muslim dalam lintas disiplin ilmu.

3. Munculnya beberapa disiplin ilmu baru: Sains Islam dan Ilmu-ilmu Sosial Islam.

\section{SIMPULAN}

Dari uraian diatas dapat dipahami bahwa dalam beberapa hal, antara alAttas dengan al-Faruqi mempunyai kesamaan pandangan, seperti pada tataran epistemologi mereka sepakat bahwa ilmu tidak bebas nilai (value free) tetapi terikat (value bound) dengan nilainilai yang diyakini kebenarannya. Mereka juga sependapat bahwa ilmu mempunyai tujuan yang sama yang konsepsinya disandarkan pada prinsip metafisika, ontologi, epistemologi dan aksiologi dengan tauhid sebagai kuncinya. Mereka juga meyakini bahwa Allah adalah sumber dari segala ilmu dan mereka sependapat bahwa akar permasalahan yang dihadapi umat Islam saat ini terletak pada sistem pendidikan yang ada, khususnya masalah yang terdapat dalam ilmu kontemporer. Dalam pandangan mereka, ilmu kontemporer atau sains modern telah keluar dari jalur yang seharusnya. Sains modern telah menjadi "virus" yang menyebarkan penyakit yang berbahaya bagi keimanan umat Islam sehingga unsur-unsur buruk yang ada di dalamnya harus dihapus, dianalisa, dan ditafsirkan ulang sesuai dengan nilai-nilai dan ajaran Islam.
Walaupun cukup banyak persamaan yang terdapat di antara keduanya, dalam beberapa hal, secara prinsip, mereka berbeda. Untuk mensukseskan proyek Islamisasi, al-Attas lebih menekankan kepada subjek daripada ilmu, yaitu manusia, dengan melakukan pembersihan jiwa dan menghiasinya dengan sifat-sifat terpuji, sehingga dalam proses Islamisasi ilmu tersebut dengan sendirinya akan terjadi transformasi pribadi serta memiliki akal dan rohani yang telah menjadi Islam secara kaffah. Sedangkan al-Faruqi lebih menekankan pada objek Islamisasi yaitu disiplin ilmu itu sendiri. Hal ini mungkin saja menimbulkan masalah, khususnya ketika berusaha untuk merelevansikan Islam terhadap sains modern, karena bisa saja yang terjadi hanyalah proses labelisasi atau ayatisasi semata.

Terdapat juga perbedaan yang cukup mencolok mengenai ruang lingkup yang perlu diislamkan. Dalam hal ini, alAttas membatasi hanya pada ilmu-ilmu pengetahuan kontemporer atau masa kini sedangkan al-Faruqi meyakini bahwa khazanah keilmuan Islam masa lalu juga perlu untuk diislamkan kembali sebagaimana yang telah dia canangkan di dalam kerangka kerjanya. Dan satu hal lagi, dalam metodologi bagi proses Islamisasi ilmu, al-Attas berpandangan bahwa definisi Islamisasi itu sendiri telah memberi panduan kepada metode pelaksanaannya di mana proses ini melibatkan dua langkah sebagaimana telah dijelaskan sebelumnya. Sedangkan bagi al-Faruqi, hal itu belumlah cukup sehingga ia merumuskan suatu kaedah untuk Islamisasi ilmu pengetahuan berdasarkan prinsip-prinsip pertamanya yang melibatkan 12 langkah.

Perbedaan yang lain adalah AlFaruqi mengecilkan peranan tasawuf dan berpendapat bahwa "kerohanian yang terpancar melalui tasawwuf hanya membawa kepada kelesuan dan karena itu ia beranggapan bahwa tasawuf itu 
sesuatu yang tidak perlu dan bahkan bisa merusak." Semantara al-Attas menganggap tasawuf bukan saja penting tetapi perlu bagi perumusan teori ilmu dan pendidikan.

Konsep Islamisasi al-Faruqi lebih menekankan masyarakat, ummah atau perubahan sosio-ekonomi dan politik. Malahan ia lebih gencar menyebarkan ide Islamisasi ilmu kepada massa melalui aktivitas tetap yang berbentuk seminar, persidangan dan membuka beberapa cabangnya di beberapa negara. Konsep islamisasi ilmu pengetahuan al-Attas juga mnemberi lebih perhatian kepada individu daripada masyarakat. Baginya perubahan individual akan diikuti oleh perubahan dalam masyarakat dan ummah.

Pendekatan yang berbeda antara
al-Attas dan al-Faruqi dalam menkonseptualisasikan Islamisasi ilmu pengetahuan kontemporari tidak perlu diperbesar-besarkan. Yang penting keduanya ikhlas dan bersungguhsungguh memikirkan jalan keluar bagi kegentingan umat Islam.

\section{DAFTAR KEPUSTAKAAN}

Azra, Azyumardi. (1996). Pergolakan Politik Islam dan Fundamentalisme Modern hingga Post-Modernism, Jakarta, Paramadina.

Daud, Wan Mohd Nor Wan. (1998). The Educational Philosophy and Practice of Syed Muhammad Naquib al-Attas, diterjemahkan oleh Hamid Fahmy dkk, Filsafat dan Praktik Pendidikan Islam Syed M. Naquib al-Attas Bandung: Mizan.

Hashim, Rosnani. (2005). Gagasan Islamisasi Kontemporer: Sejarah, Perkembangan dan Arah Tujuan, dalam Islam: Majalah Pemikiran dan Peradaban Islam INSIST, Jakarta: Thn II No.6/ Juli-September. http://blog.uinmalang.ac.id/amin/2010/ 09/21/profil-dan-pemikiran-ismailraji-al-faruqi/. Diakases Kamis, 29 Maret 2018.

http://iptekita.com/content/view/14/26 /. Diakases Kamis, 29 Maret 2018.

http://kacongmadura.multiply.com/jour nal/item/2/Islamisasi_Ilmu_Pengeta huan. Diakases Kamis, 29 Maret 2018.

http://limalaras.wordpress.com/2010/0 4/26/download-makalah-sejarah/

http://tutorq.blogspot.com/2010/07/pe mikiran-syed-muhammad-naquibal-attas.html. Diakases Kamis, 29 Maret 2018.

http://www.wayofmuslim.com/portal/ar ticle.php?story=2009041208400171 7. Diakases Kamis, 29 Maret 2018.

Muhaimin, H. (2006). Nuansa Baru Pendidikan Islam; Mengurangi Benang Kusut Dunia Pendidikan, Jakarta: Raja Grafindo Persada,.

Nata, Abuddin dkk. (2002). Integrasi IImu Agama \& Ilmu Umum, Jakarta: Raja Grafindo Persada.

Nizar, Samsul. (2002). Filsafat Pendidikan Islam, Jakarta: Ciputat Pers.

Sholeh, S. (2017). Islamisasi Ilmu Pengetahuan (Konsep Pemikiran Ismail Raji Al-Faruqi dan Syed Muhammad Naquib Al-Attas). AlHikmah: Jurnal Agama dan Ilmu Pengetahuan, 14 (2), 209-221.

Tafsir, Ahmad. (2014). Filsafat Ilmu: Mengurai Ontologi, Epistemologi dan Aksiologi Pengetahuan Bandung: PT. Remaja Rosdakarya. 